원주 법천사지 지광국사탑 복원부 모르타르 재료학적 특징 및 표면손상 기초 해석

\title{
Analysis on Material Characteristics of Restored Areas with Mortar and Basis of Surface Deterioration on the Stupa of State Preceptor Jigwang from Beopchensaji Temple Site in Wonju, Korea
}

\author{
채승아, 조하진, 이태종 ${ }^{*}$ \\ 국립문화재연구소 문화재보존과학센터 \\ Seung A Chae, Ha Jin Cho, Tae Jong Lee* \\ Conservation Sciences Center, National Research Institute of Cultural Heritage, Daejeon 34122, Korea
}

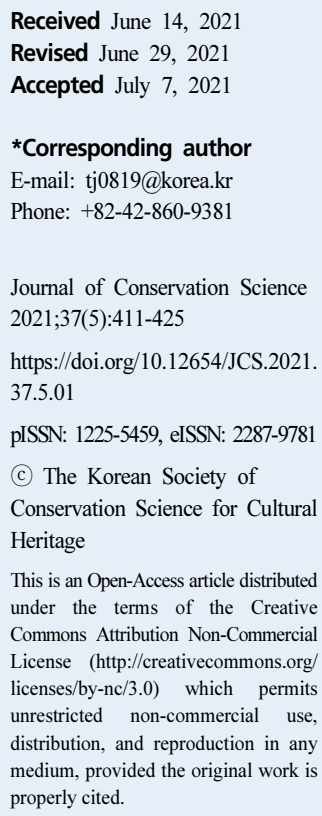

\begin{abstract}
초 록 원주 법천사지 지광국사탑은 조성시기와 대상이 명확하며, 뛰어난 장엄조각과 화려한 문양이 새겨진 고려시대를 대표하는 승탑이다. 그러나 한국전쟁 당시 폭격으로 파손되어 1957년 시멘트와 철근 등으로 수리·복원하였으며, 오랫동안 복원부 모르타르의 영향으로 원형부재 표면에 손 상이 진행되고 있었다. 이러한 손상원인을 확인하기 위해 복원부 모르타르와 원형부재의 풍화 산물인 표면오염물을 분석하였다. 복원부 모르타르에서는 수산화칼슘, 방해석, 에트링자이트, 이수석고를 확인하였으며, $\mathrm{pH}$ 측정과 중성화 반응검사를 통해 모르타르는 열화가 진행 중임을 알 수 있었다. 표면오염물 분석에서도 난용성 물질인 방해석, 이수석고가 확인되었고, 현미경 관찰을 통해 조암광물 사이에서 부피 성장 중인 모습도 관찰되었다. 이러한 분석 결과를 바탕 으로 표면손상 기초 해석을 위해 염 결정 형성에 큰 영향을 미치는 칼슘과 황의 함량을 P-XRF 를 이용하여 반정량 분석하였으며, 모르타르의 영향을 받은 탑신석과 영향을 받지 않은 상층기 단석을 비교하여 교차 검증하였다. 그 결과 해당 원소들이 탑신석의 표면손상에 직접적으로 관여한 것으로 판단된다.
\end{abstract}

\section{중심어 지광국사탑, 모르타르, 표면오염물, 표면손상}

ABSTRACT The Stupa of State Preceptor Jigwang from Beopcheonsa Temple Site in Wonju (National Treasure) is a representative stupa of the Goryeo Dynasty, with outstanding Buddhist carvings and splendid patterns, clearly indicating its honoree and year of construction. However, it was destroyed by bombing during the Korean War (1950-1953) and repaired and restored with cement and reinforcing bars in 1957. The surface condition of the original stone shows long-term deterioration due to the mortar used in past restorations. In order to identify the exact causes of deterioration, the mortar and surface contaminants on the original stone were analyzed. Portlandite, calcite, ettringite, and gypsum from the mortar were identified, and its ongoing deterioration was observed through $\mathrm{pH}$ measurements and the neutralization reaction test. Analysis of surface contaminants identified calcite and gypsum, both poorly water-soluble substances, and their growth in volume among rock-forming minerals was observed by microscopy. Based on those results, semi-quantitative analysis of $\mathrm{Ca}$ and $\mathrm{S}$ contents significantly influencing the formation of salt crystals was conducted using P-XRF to analyze the basis of surface deterioration, and cross-validation was performed by comparing the body stone affected by the mortar and the upper stylobate stone unaffected by the mortar. Results indicate that the elements are directly involved in the surface deterioration of the body stone.

Key Words Stupa of the State Preceptor Jigwang, Mortar, Surface contaminants, Surface deterioration 


\section{1. 서 론}

원주 법천사지 지광국사탑(이하 ‘지광국사탑’)은 고려 시대 때 국가에서 최고의 승려에게 내리는 '왕사(王師)'와 '국사(國師)'의 칭호를 받았던 지광국사 해린(984 1067) 을 기리기 위해 세운 승탑이다. 석탑을 살펴보면 탑 전체 에 여러 가지 꾸밈을 두었으며 각 암석면에 새겨진 정교 한 조각과 문양은 그 시대의 보편적인 승탑과는 구분되는 특수성을 가지고 있어 한국 미술사에서 중요한 의미를 갖 는 석탑으로 1962년 국보에 지정되었다(Cultural Heritage Conservation Science Center, 2017).

지광국사탑은 일제강점기인 1911년 일본인에 의해 옮 겨져 국립고궁박물관 옆 위치로 오기까지 최소 9차례 해 체 - 이건되었다. 특히 한국전쟁 시 폭격으로 인해 옥개 석을 비롯한 상륜부가 여러 조각으로 크게 파손되어 1957년 시멘트, 철근 등을 이용하여 수리 - 복원을 진행 하였다(Cultural Heritage Conservation Science Center, 2017).

모르타르를 사용한 복원부는 총 29개(사자상 제외) 부 재 중 18 개에서 확인되었고, 부재별 사용량은 각기 다르 다. 모르타르 복원부는 석탑 전체 표면적의 약 $4.6 \%$ 를 차 지하며 이 중 한국전쟁으로 가장 크게 파손된 옥개석은 모르타르와 철근 등을 이용하여 전체 면적의 $47.4 \%$ 이상 수리 - 복원하였다. 당시 최신 재료를 사용한 것이었지만 사계절 내내 외부에 노출되어 있는 지광국사탑의 특성상 비, 눈 등 외부 환경요인으로 일부 복원부에서 모르타르 와 원형부재 간의 균열과 이격이 발생하고 있었다. 또한 원형부재 표면에서는 백화현상을 비롯한 미세균열, 박리, 박락, 입상분해 등 풍화 현상이 확인되었다. 특히 옥개석 바로 아래 위치한 탑신석에서 표면손상이 집중적으로 확 인되었다.

1957년 지광국사탑 수리·복원에 사용한 포틀랜드 시 멘트는 수화생성물 중에서 다량으로 존재하는 알칼리성 의 수산화칼슘 $\left(\mathrm{Ca}(\mathrm{OH})_{2}\right)$ 이 대기오염물질과 반응하여 다 양한 표면손상을 유발시키게 된다(Kim et al., 2006). 본 연구에서는 이와 같은 원형부재의 표면손상이 나타나는 원인을 알기 위해 1957년에 수리·복원을 진행한 지광국 사탑 복원부에 사용한 모르타르와 지광국사탑 부재 중 옥 개석, 탑신석, 상층기단석 표면의 흑색 및 백색 오염물 탈 락 편을 수습하여 과학적 분석을 수행하였다. 분석 결과 를 통해 원형부재의 표면손상을 유발하는 원인물질을 확 인하였으며, 모르타르가 지광국사탑 표면에 어떤 영향을 미치고 있는지 해석하였다.

\section{2. 현황 및 연구방법}

\section{1. 현황}

지광국사탑은 정기조사(2005년, 2010년), 문화재 특별 종합점검(2014 2015년), 정밀안전진단(2015년) 등의 결 과, 다수의 크고 작은 균열과 시멘트 복원 부위 탈락, 이 격 등이 확인되었으며 기단부와 시멘트로 복원된 옥개석, 상륜부의 구조적 불안정까지 더해져 석탑의 추가적 손상 이 우려되는 상황이었다. 이에 문화재위원회에서 전면해 체 - 보존처리 결정하여, 2016년 4월 국립고궁박물관에서 국립문화재연구소 문화재보존과학센터로 해체- 이전하 여 보존처리를 진행하였다(Cultural Heritage Conservation Science Center, 2017).

해체 전 보존현황은 균열, 탈락, 박리, 박락, 입상분해 등 물리적 손상과 흑색과 백색, 갈색 등 화학적 손상에 의한 표면오염물이 관찰되었다. 원형부재 표면의 오염물 은 크게 흑색과 백색으로 구분되며 대부분 각 부재 바닥 면에 우세하게 확인되었다. 또한 원형부재와 복원부 모르 타르 사이에 균열과 이격이 있었고, 해당 공간에 오염물 과 미생물이 성장할 수 있는 환경이 만들어져 이차적 손 상이 나타나고 있었다. 특히 탑신석은 문양이 조각되어 있는 부분에 백화현상이 집중되고 박리, 박락, 입상분해 로 인해 조각 문양이 사라지는 표면풍화가 진행 중이었 다. 더불어 해체 후 복원부 모르타르 제거 과정에서 원형 부재와 복원부를 지지하는 원형철근 및 반선 등 다수의 철물에서 부식생성물이 관찰되었다(Figure 1).

\section{2. 연구방법}

지광국사탑 복원부에 사용된 모르타르 제거 중 탈락편 의 단면 관찰 결과, 복원부는 같은 모르타르를 사용한 것 이 아니라 1 4개의 다른 층을 형성하고 있어 색상과 입 자별로 구분한 후 해당 모르타르의 손상 정도를 정량적으 로 평가하였다.

먼저 복원부 모르타르의 구분에 따른 조직관찰, 조성, 분포양상을 분석하였다. 조직관찰을 위해 광학현미경 (LEICA, DEMZ-12 Axiotech 100HD, DEU) 및 편광현미경 (NIKON, LV100NPOL, JPN), 주사전자현미경 관찰(JEOL, JSM-IT300, JPN)을 실시하였고, 이후 에너지분산형 분석 기(X-MAX ${ }^{\mathrm{N}}$, Oxford, GBR)를 활용하여 성분을 분석하였 다. 이때 시료는 벌크상태로 백금(Pt) $10 \mathrm{~mA}$ 에서 30초간 코팅하였으며, 분석조건은 가속 전압 $10 \sim 15 \mathrm{kV}$, 분석거 리는 $10 \mathrm{~mm}$ 이다. 또한 층별 조성이 어떻게 다른지 미소부 X선형광분석기(Micro X-ray Fluorescence Analyzer, Eagle 

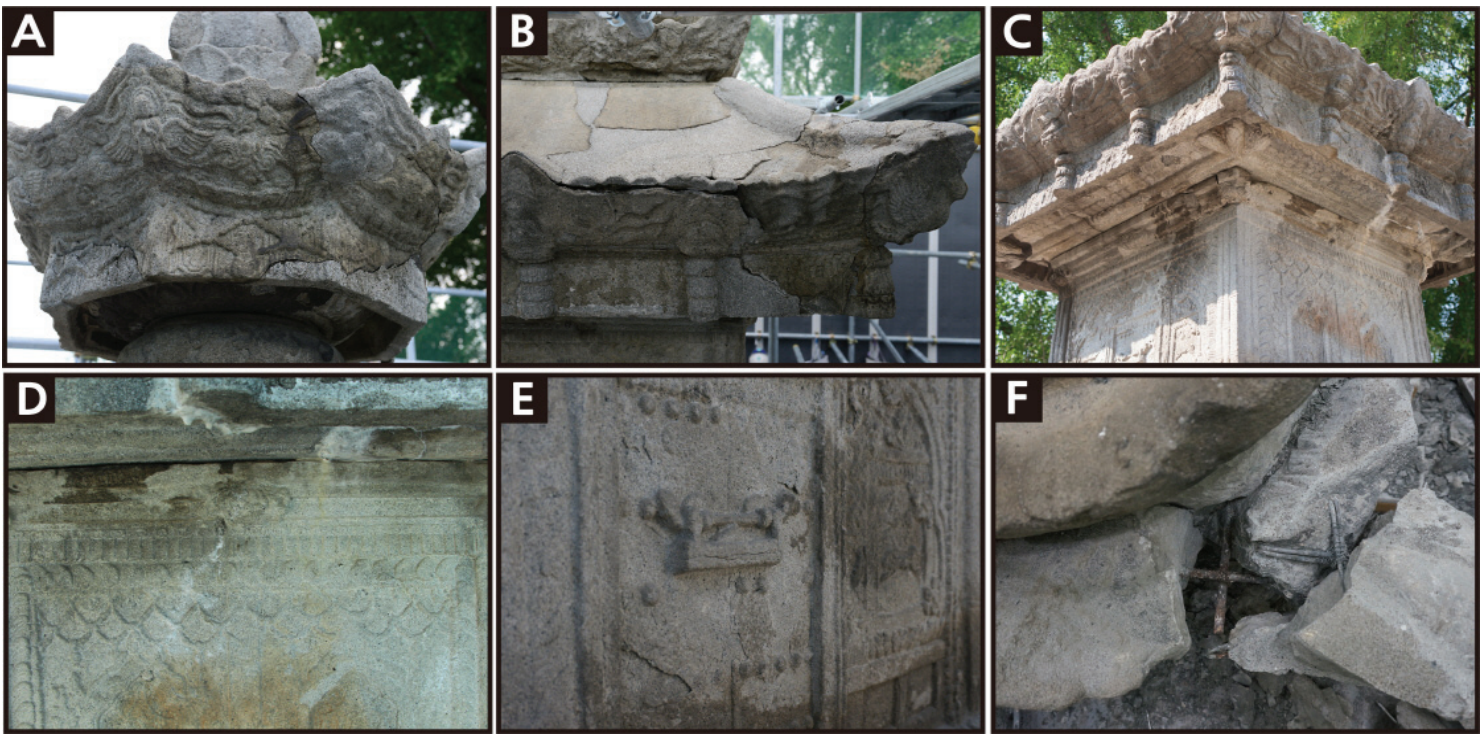

Figure 1. Deterioration types of Stupa of State Preceptor Jigwang. (A) Cracks in the mortar restoration of Decorative cover on wheel-shaped decoration, (B) Cracks and Disjoining in the mortar restoration of Roof stone, (C) Surface contaminants of Roof stone and Body stone, (D) Black \& White crust on the surface of Roof stone lower and Body stone, (E) Scaling and Exfoliation of Body stone, (F) Corrosion products of reinforcing bars inside the mortar restoration of Upward-turning petals-shaped decoration.

3-XXL, EDAX, Inc., USA)를 이용해 정량 분석하였다. 분석 조건은 $40 \mathrm{kV}, 400 \mu \mathrm{A}$, spot size는 $300 \mu \mathrm{m}$ 에서 200 초간 분석 하였고, 분석 결과는 3 번씩 분석해 평균값을 계산하였다.

결정상태 및 광물의 동정을 위해 Empyrean(PANanlytical, $\mathrm{NLD}$ )를 활용하여 $\mathrm{X}$ 선 회절분석(XRD)을 실시하였다. 사용 된 X선은 $\mathrm{Cu} K_{a}$, 가속전압과 전류는 $45 \mathrm{kV} / 40 \mathrm{~mA}$ 이며, $5^{\circ}$ $60^{\circ} 2 \theta$ 구간에서 0.02 초 연속스캐닝으로 회절값을 기록했다.

모르타르의 열화 상태를 알아보기 위한 중성화 실험으 로, $\mathrm{pH}$ 측정(Thermo Scientific, Orion 3-star benchtop $\mathrm{pH}$ Meter)과 페놀프탈레인 $1 \%$ 용액을 이용한 중성화 반응검 사를 실시하였다.

마지막으로 원형부재에 나타나는 표면손상 원인을 알 기 위해 옥개석과 탑신석의 흑색과 백색오염물, 상층기단 석 흑색오염물의 탈락편을 수습하여 분석하였다. 시료의 조직관찰과 성분을 분석하기 위해 SEM-EDX를 활용하였 으며 결정광물 동정을 위해 $\mathrm{XRD}$ 를 수행하였다. 분석 장 비 및 조건은 모르타르 분석 방법과 동일하였으며 분석대 상이 문화재임을 고려하여 극미량의 시료를 분석하였다.

\section{3. 복원부 모르타르의 재료학적 특성}

\section{1. 복원부 모르타르 산출상태 및 분류}

지광국사탑 복원부는 시멘트와 물만을 반죽한 시멘트
페이스트와 잔골재(입경 $5 \mathrm{~mm}$ 이하의 모래)가 들어간 모 르타르, 굵은 골재가 들어간 콘크리트로 구성되어 있다. 또한 복원 방법에 따라 탑의 파손된 부분을 철근 콘크리 트로 복원함으로써 결실부분 복원과 구조적 안정성을 함 께 부여하기 위한 수리 - 복원, 그리고 조각 부분의 의장 적 요소 또는 도상을 복원하기 위해 형태적 성형에 초점 을 맞춘 수리·복원으로 구분할 수 있다.

이 연구에서는 구조안정성 측면에서의 접근은 제외하 고, 원형부재 표면손상에 영향을 끼치는 것으로 판단되는 형태적 성형에 사용된 모르타르의 재료학적 특성을 파악 하였다.

먼저 복원부 모르타르는 육안관찰을 통해 색상과 입자 크기로 분류하였는데, 노란색을 띠는 회색(황회색, yellow gray - 유형 1), 밝은 회색(담회색, light gray - 유형 2), 어 두운 회색(암회색, Dark gray - 유형 3), 검은빛을 띠는 회 색(흑회색, Black gray - 유형 4) 총 4가지 유형으로 분류된 다(Figure 2).

유형 1 은 불규칙적인 검은색 입자가 없고 옥개석과 탑 신석의 복원부 모르타르 최외각 면에서만 나타났다. 유형 2 와 유형 3 은 $5 \mathrm{~mm}$ 이하의 불규칙적 백색과 검은색 입자 가 관찰되었고, 유형 4는 불규칙적인 검은색 입자는 없으 나 조밀한 구멍들이 보였다. 모든 복원부가 동일하게 유 형을 형성하고 있진 않으며 각 부재별로 복합적인 형태를 가지고 있는 복원부도 있었다. 

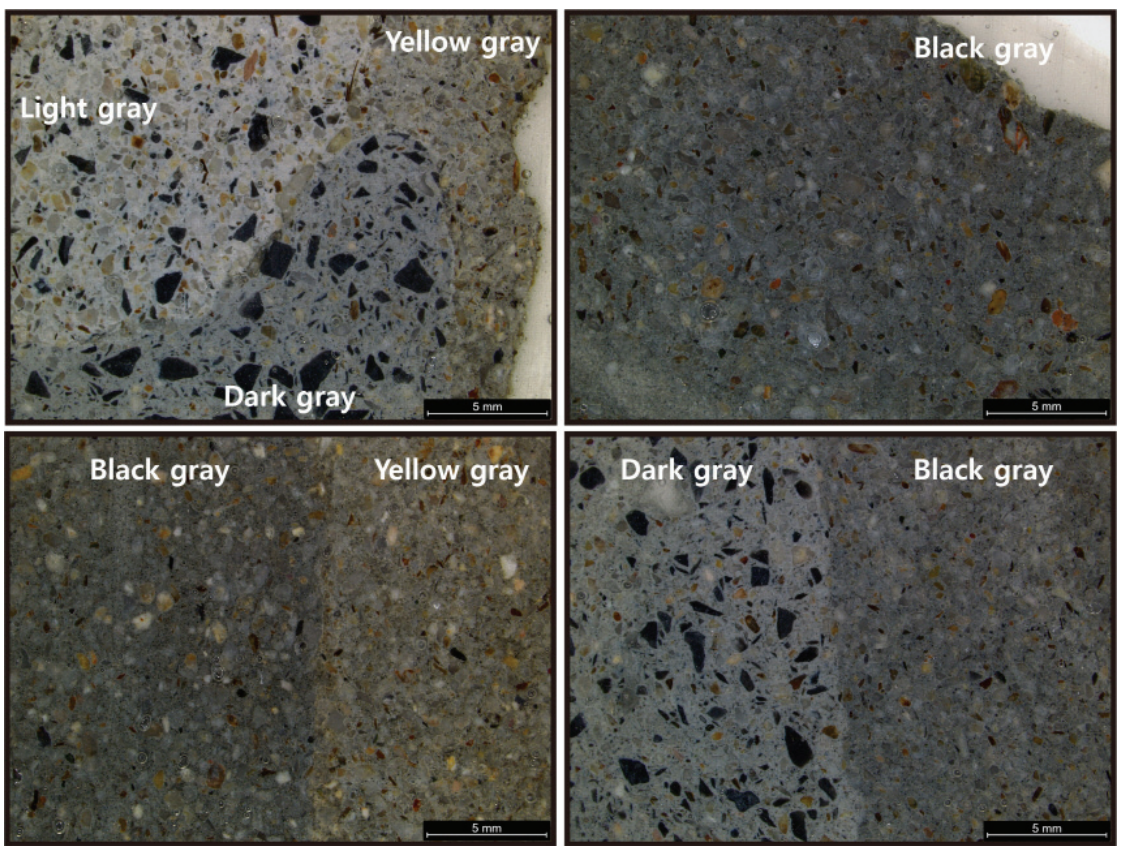

Figure 2. Macroscopy of representative mortar samples.

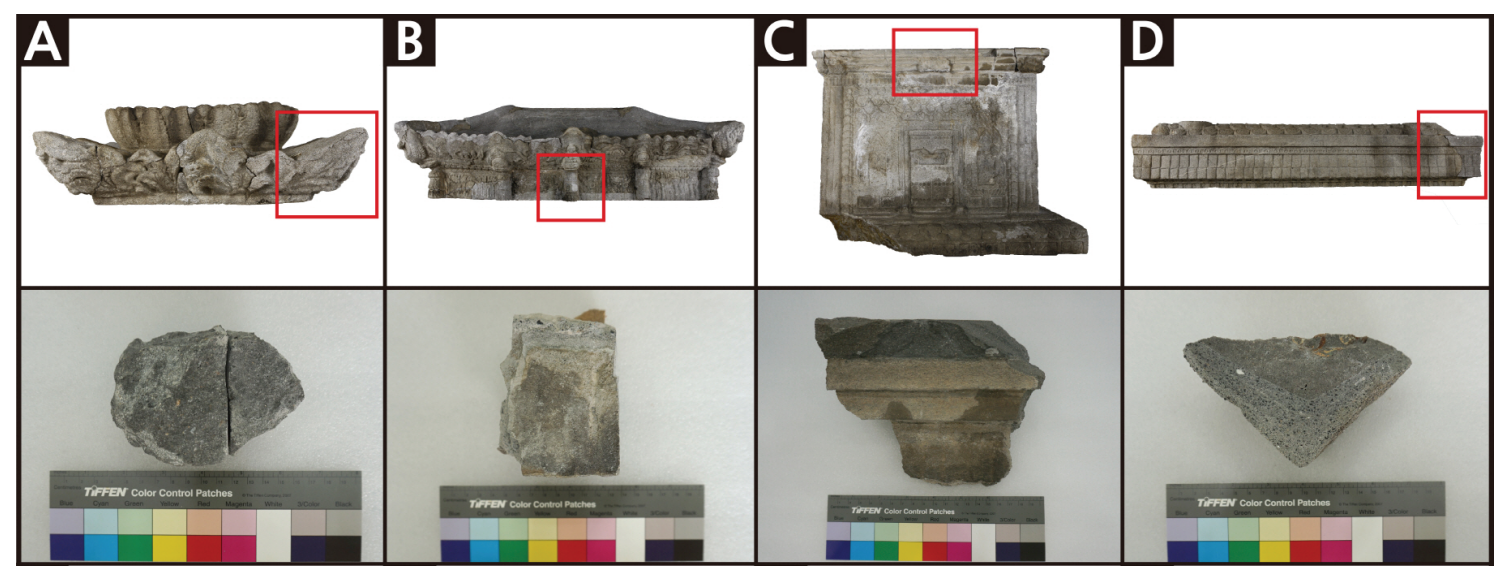

Figure 3. Representative mortar samples for analysis. (A) Upward-turning petals-shaped decoration_ES, (B) Roof stone_N, (C) Body stone_N, (D) Cover stone of lower stylobate_SW.

지광국사탑 복원부의 유무와 모르타르의 색상별 분류 는 다음 Table 1 과 같다. 분석대상 시료는 유형 $1 \sim 4$ 까지 동일하게 확인되는 앙화, 옥개석, 탑신석, 하층기단갑석 의 복원부 모르타르를 대표시료로 선정하였으며 수습된 시료의 위치는 다음과 같다(Figure 3).

\section{2. 복원부 모르타르 미세조직 관찰}

육안관찰로 분류한 유형을 보다 명확히 구분하고 미세 구조나 조직을 확인하기 위해 광학현미경과 편광현미경
을 이용하여 시편을 관찰하였다.

유형 1 의 경우 아각상 내지 아원상, 각상의 원마도를 보이며 분급은 보통이다. 전체적으로 방해석이 많이 보이 고, $1 \mathrm{~mm}$ 이하의 석영과 운모, 장석류가 관찰되며 일부 풍화되어 견운모화 진행된 장석들이 확인되었다(Figure $4 \mathrm{~A})$. 유형 2 의 경우 각상, 아각상의 원마도를 보이며 분급 은 불량이다. 석영, 운모, 장석류가 많이 보이며 시멘트 페이스트 기질이 4개의 시료 중 가장 밝다(Figure 4B). 유 형 3 의 경우 각상 내지 아각상의 원마도를 보이고 분급은 불량이다. 석영, 운모, 장석류, 방해석 등이 보이며 다른 
Table 1. State of remaining mortar and its color classification on surface of each part

\begin{tabular}{|c|c|c|c|c|c|c|c|}
\hline \multirow{3}{*}{ NO. } & \multirow{3}{*}{$\begin{array}{c}\text { Name of } \\
\text { stone properties }\end{array}$} & \multirow{3}{*}{ Direction } & \multirow{3}{*}{$\begin{array}{c}\text { Status of } \\
\text { Mortar } \\
\mathrm{O} / \mathrm{X}\end{array}$} & \multicolumn{4}{|c|}{ Mortar color classification } \\
\hline & & & & Type 1 & Type 2 & Type 3 & Type 4 \\
\hline & & & & $\begin{array}{l}\text { Yellow } \\
\text { gray }\end{array}$ & $\begin{array}{l}\text { Light } \\
\text { gray }\end{array}$ & $\begin{array}{l}\text { Dark } \\
\text { gray }\end{array}$ & $\begin{array}{c}\text { Black } \\
\text { gray }\end{array}$ \\
\hline 1 & $\begin{array}{c}\text { Boju } \\
\text { (Bead-shaped decoration on the top) }\end{array}$ & & $\mathrm{O}$ & & & $\mathrm{O}$ & \\
\hline 2 & $\begin{array}{c}\text { Bogae } \\
\text { (Decorative cover on wheel-shaped decoration) }\end{array}$ & & $\mathrm{O}$ & & & $\mathrm{O}$ & $\mathrm{O}$ \\
\hline 3 & $\begin{array}{c}\text { Boryun } \\
\text { (Wheel-shaped decoration) }\end{array}$ & & $\mathrm{O}$ & & & $\mathrm{O}$ & \\
\hline 4 & $\begin{array}{c}\text { Anghwa } \\
\text { (Upward-turning petals-shaped decoration) }\end{array}$ & & $\mathrm{O}$ & & & $\mathrm{O}$ & $\mathrm{O}$ \\
\hline 5 & $\begin{array}{l}\text { Okgaeseok } \\
\text { (Roof stone) }\end{array}$ & & $\mathrm{O}$ & $\mathrm{O}$ & $\mathrm{O}$ & $\mathrm{O}$ & \\
\hline 6 & $\begin{array}{l}\text { Tapsinseok } \\
\text { (Body stone) }\end{array}$ & & $\mathrm{O}$ & $\mathrm{O}$ & & & $\mathrm{O}$ \\
\hline 7 & $\begin{array}{c}\text { Tapsinbatchimseok } \\
\text { (Support stone under body stone) }\end{array}$ & & $\mathrm{X}$ & - & - & - & - \\
\hline 8 & $\begin{array}{c}\text { Sangcheunggidangapseok } \\
\text { (Cover stone of upper stylobate) }\end{array}$ & & $\mathrm{O}$ & & & $\mathrm{O}$ & \\
\hline 9 & $\begin{array}{l}\text { Sangcheunggidanseok } \\
\text { (Upper stylobate stone) }\end{array}$ & & $\mathrm{O}$ & & $\mathrm{O}$ & & \\
\hline 10 & $\begin{array}{l}\text { Sangcheunggidanbatchimseok } \\
\text { (Bottom stone of upper stylobate) }\end{array}$ & & $\mathrm{X}$ & - & - & - & - \\
\hline 11 & $\begin{array}{c}\text { Hacheunggidangapseok } \\
\text { (Cover stone of lower stylobate) }\end{array}$ & & $\mathrm{O}$ & & $\mathrm{O}$ & $\mathrm{O}$ & $\mathrm{O}$ \\
\hline \multirow{4}{*}{12} & \multirow{4}{*}{$\begin{array}{l}\text { Hacheunggidanseok } \\
\text { (Lower stylobate stone) }\end{array}$} & SW & $\mathrm{O}$ & & $\mathrm{O}$ & $\mathrm{O}$ & $\mathrm{O}$ \\
\hline & & $\mathrm{WN}$ & $\mathrm{O}$ & & & $\mathrm{O}$ & $\mathrm{O}$ \\
\hline & & $\mathrm{NE}$ & $\mathrm{O}$ & & & $\mathrm{O}$ & \\
\hline & & $\mathrm{ES}$ & $X$ & - & - & - & - \\
\hline \multirow{4}{*}{13} & \multirow{4}{*}{$\begin{array}{c}\text { Jidaeseok } \\
\text { (Foundation stone) }\end{array}$} & SW & $\mathrm{O}$ & & $\mathrm{O}$ & $\mathrm{O}$ & $\mathrm{O}$ \\
\hline & & $\mathrm{WN}$ & $\mathrm{O}$ & & & $\mathrm{O}$ & $\mathrm{O}$ \\
\hline & & $\mathrm{NE}$ & $X$ & - & - & - & - \\
\hline & & ES & $X$ & - & - & - & - \\
\hline \multirow{4}{*}{14} & \multirow{4}{*}{$\begin{array}{c}\text { Tapguseok upper } \\
\text { (Upper decorative boundary stone) }\end{array}$} & $\mathrm{S}$ & $\mathrm{O}$ & & $\mathrm{O}$ & & \\
\hline & & $\mathrm{W}$ & $X$ & - & - & - & - \\
\hline & & $\mathrm{N}$ & $\mathrm{O}$ & & $\mathrm{O}$ & $\mathrm{O}$ & \\
\hline & & E & $\mathrm{O}$ & & $\mathrm{O}$ & & \\
\hline \multirow{4}{*}{15} & \multirow{4}{*}{$\begin{array}{c}\text { Tapguseok lower } \\
\text { (Lower decorative boundary stone) }\end{array}$} & $\mathrm{S}$ & $X$ & - & - & - & - \\
\hline & & $\mathrm{W}$ & $\mathrm{X}$ & - & - & - & - \\
\hline & & $\mathrm{N}$ & $X$ & - & - & - & - \\
\hline & & $\mathrm{E}$ & $X$ & - & - & - & - \\
\hline \multirow{4}{*}{16} & \multirow{4}{*}{$\begin{array}{c}\text { Useok } \\
\text { (Corner stone) }\end{array}$} & SW & $X$ & - & - & - & - \\
\hline & & $\mathrm{WN}$ & $X$ & - & - & - & - \\
\hline & & $\mathrm{NE}$ & $\mathrm{O}$ & & $\mathrm{O}$ & & \\
\hline & & ES & $X$ & - & - & - & - \\
\hline
\end{tabular}




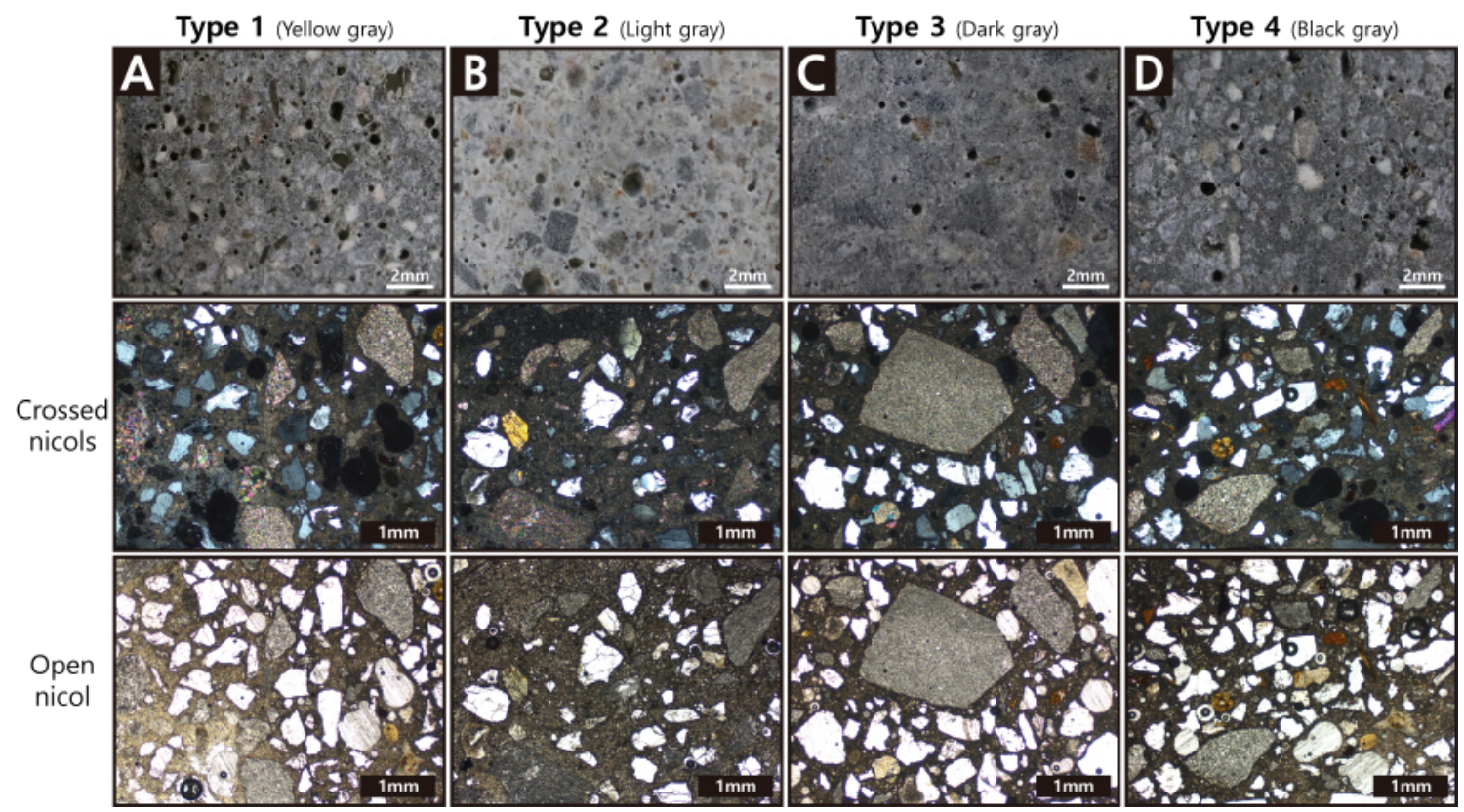

Figure 4. Images by Microscopy \& Polarizing microscopy of representative mortar samples. (A) Type 1, (B) Type 2, (C) Type 3, (D) Type 4.

시료에선 볼 수 없었던 $1 \mathrm{~mm}$ 이상의 광물입자들이 보인다 (Figure 4C). 유형 4의 경우 아각상, 각상 입자의 원마도를 가지며 분급은 불량이다. 석영, 운모, 장석류, 방해석 등이 보이며 특징적으로 유색광물이 많이 보인다(Figure 4D).

모든 시료는 전반적으로 조직이 치밀하지 않고 공극이 많고, 시멘트와 잔골재가 혼합된 형태로 미정질부터 세립 질까지 다양한 크기로 구성되어 있으며, 시료에 따라 기 질 내 광물의 응집도 또한 차이가 있다.

\section{3. 복원부 모르타르 유형별 화학조성}

모르타르 시료들의 주성분은 $\mathrm{MgO}, \mathrm{Al}_{2} \mathrm{O}_{3}, \mathrm{SiO}_{2}, \mathrm{SO}_{3}$, $\mathrm{K}_{2} \mathrm{O}, \mathrm{CaO}, \mathrm{TiO}_{2}, \mathrm{Fe}_{2} \mathrm{O}_{3}$ 등이 분석되었으며 주성분의 함량 은 Table 2와 같다. 시멘트의 색상은 시멘트 중의 알루민 산 $\left(\mathrm{Al}_{2} \mathrm{O}_{3}\right)$ 나 산화마그네슘 $(\mathrm{MgO})$, 산화제이철 $\left(\mathrm{Fe}_{2} \mathrm{O}_{3}\right)$ 등의 함유량에 따라 구분되며, 일반적으로 $\mathrm{Al}_{2} \mathrm{O}_{3}$ 가 증가하면 명도 및 노란색이 증가하고, $\mathrm{MgO}$ 나 $\mathrm{Fe}_{2} \mathrm{O}_{3}$ 이 증가하면 검 은색이 증가하고 노란색은 감소한다. 따라서 지광국사탑 복원부 모르타르의 색상 차이는 $\mathrm{Al}_{2} \mathrm{O}_{3}$ 와 $\mathrm{Fe}_{2} \mathrm{O}_{3}$ 에 기인하

Table 2. Chemical composition(wt $\%$ ) of representative mortar samples

\begin{tabular}{c|c|c|c|c|c|c|c|c|c}
\hline & \multicolumn{10}{c}{ Chemical composition(wt\%) } \\
\cline { 2 - 35 } & $\mathrm{MgO}$ & $\mathrm{Al}_{2} \mathrm{O}_{3}$ & $\mathrm{SiO}_{2}$ & $\mathrm{SO}_{3}$ & $\mathrm{~K}_{2} \mathrm{O}$ & $\mathrm{CaO}$ & $\mathrm{TiO}_{2}$ & $\mathrm{Fe}_{2} \mathrm{O}_{3}$ & $\mathrm{Total}^{2}$ \\
\hline Type 1 & 2.0 & 4.2 & 33.4 & 2.0 & 2.1 & 53.8 & 1.1 & 1.4 & 100 \\
\hline Type 2 & 2.0 & 4.0 & 28.8 & 1.7 & 2.3 & 59.0 & 0.28 & 1.8 & 99.9 \\
\hline Type 3 & 2.6 & 2.2 & 14.0 & 3.2 & 1.1 & 75.5 & 0.24 & 1.1 & 99.9 \\
\hline Type 4 & 1.6 & 3.8 & 29.2 & 1.3 & 1.9 & 57.6 & 0.57 & 4.2 & 100 \\
\hline
\end{tabular}

Table 3. Chemical composition(wt\%) of present common Class 1 Portland cement

\begin{tabular}{c|c|c|c|c|c|c}
\hline $\mathrm{SiO}_{2}$ & $\mathrm{Al}_{2} \mathrm{O}_{3}$ & $\mathrm{Fe}_{2} \mathrm{O}_{3}$ & $\mathrm{MgO}$ & $\mathrm{CaO}$ & $\mathrm{SO}_{3}$ & Ig.Loss \\
\hline 21.7 & 5.7 & 3.2 & 2.8 & 63.1 & 2.2 & 1.3 \\
\hline
\end{tabular}

Ig.Loss: ignition loss 
는 것으로 보여진다. 복원부 모르타르 중 가장 많은 비율 을 차지하는 유형 3 의 $\mathrm{CaO}$ 는 Table 3 의 일반적인 포틀랜 드 시멘트 $\mathrm{CaO}$ 와 비교해 보더라도 대동소이하다. 이 결 과는 백화를 발생시킬 수 있는 잠재적 요소를 가지고 있 음을 나타내며 조건만 충족된다면 충분히 염 형태로 발전 될 수 있음을 지시한다.

\section{4. 복원부 모르타르 반응생성물 분석}

\subsubsection{X선 회절분석}

지광국사탑 복원부 모르타르 구성 광물의 정확한 동정 을 위해 시료를 분쇄한 후 X선 회절분석 실시하였다. 분 석 결과, 4개의 대표 시료에서 전반적으로 수산화칼슘 (Portlandite, $\left.\mathrm{Ca}(\mathrm{OH})_{2}\right)$, 방해석 $\left(\mathrm{Calcite}, \mathrm{CaCO}_{3}\right)$, 에트링자이 트(Ettringite, $3 \mathrm{CaO} \cdot \mathrm{Al}_{2} \mathrm{O}_{3} \cdot 3 \mathrm{CaSO}_{4} \cdot 32 \mathrm{H}_{2} \mathrm{O}$ ), 이수석고 (Gypsum, $\mathrm{CaSO}_{4} \cdot 2 \mathrm{H}_{2} \mathrm{O}$ )가 동정되었고, 잔골재에서 기인 된 석영 $\left(\mathrm{Quartz}, \mathrm{SiO}_{2}\right)$ 도 확인되었다.

시멘트 수화작용에 관여하는 수산화칼슘은 유형 1을
제외한 유형 2 4에선 동정되었고, 에트링자이트는 4개 의 시료 모두 검출되었다. 유형 1 3의 경우 방해석과 이 수석고가 동정되었으나 유형 4는 검출되지 않았다. 또한 유형 2 3은 다른 시료와 비교하여 방해석의 회절강도가 높게 나타났다(Figure 5).

\subsection{2. 주사전자현미경 관찰 및 분석}

SEM-EDX 분석 결과 공극 안의 이수석고 틈새에 얇고 긴 막대기 모양의 에트링자이트가 다소 규칙적인 배열을 보이고 있으며(Figure 6A), 석영 위로 성장 중인 이수석고 가 관찰되었다(Figure 6B). 아울러 시멘트 페이스트에 미 세균열도 관찰되었는데, 알칼리 골재반응 중 알칼리-실리 카 반응에 의한 것으로 판단된다(Figure $6 \mathrm{C}$ ). 시멘트의 주 요 수화 생성물인 육각판상형의 수산화칼슘 $\left(\mathrm{Ca}(\mathrm{OH})_{2}\right)$ 과 판상 사이에 형성되어 있는 에트링자이트도 확인하였고 (Figure 6D), 일부 공극에서는 방해석이 형성되어 있었다 (Figure 6E).

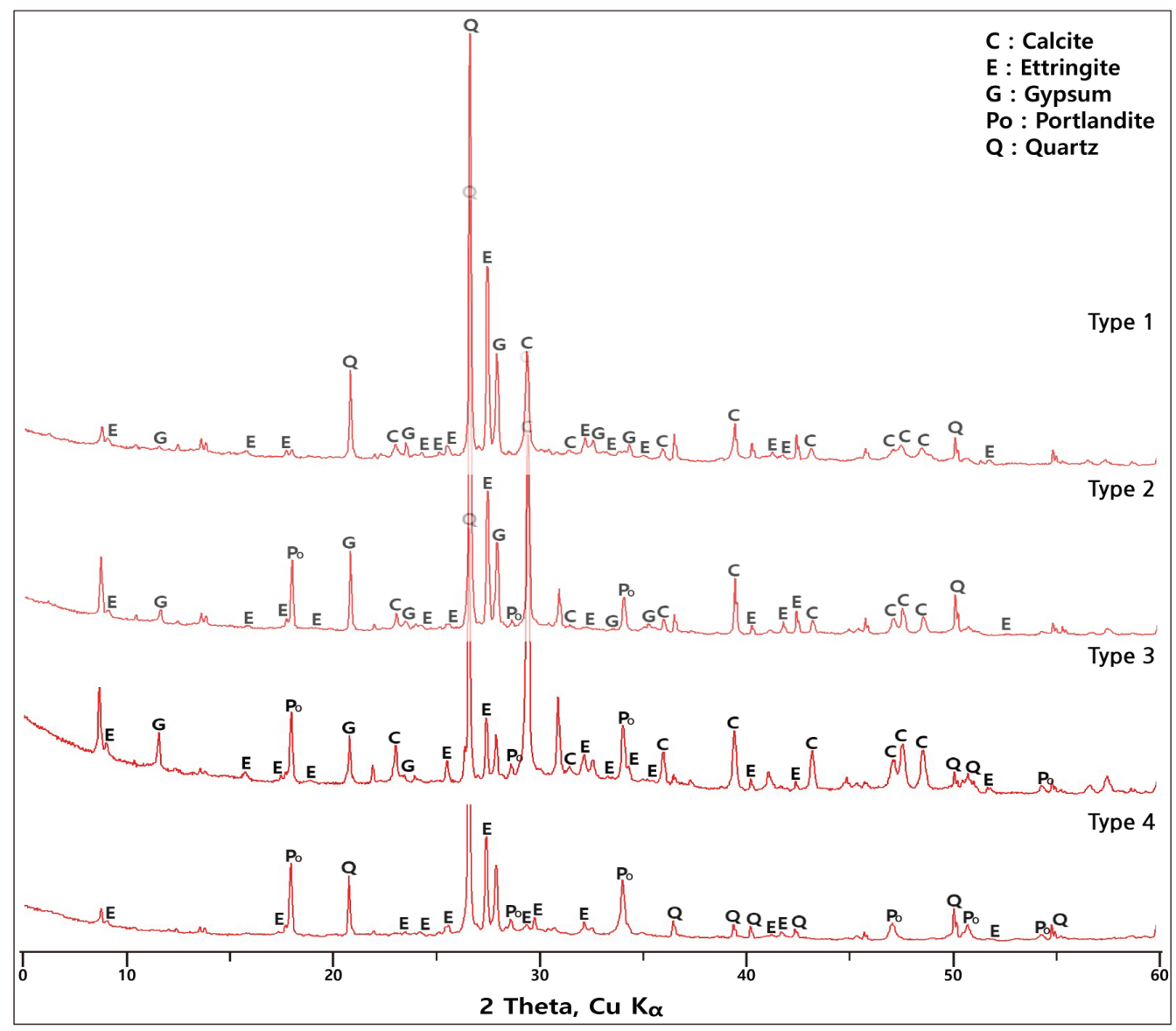

Figure 5. Analysis results of mortar samples by X-ray diffraction patterns. 

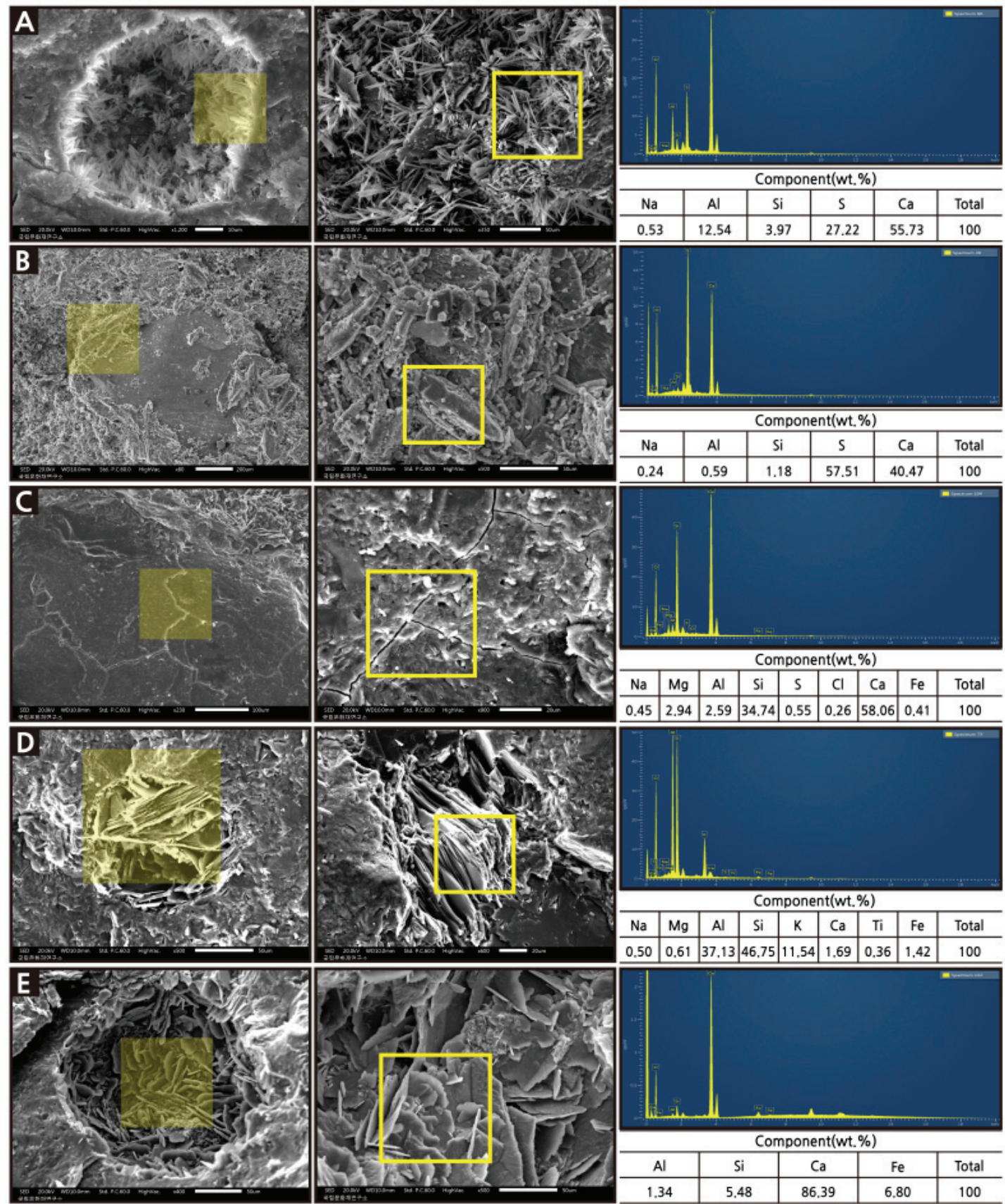

Figure 6. Scanning electron microphotographs and energy dispersive spectrum of analyzed mortar samples. (A) Ettringite formed in pores, (B) Gymsum formed over quartz, (C) Alkali-calcium-silica gel(Microcracks in cement paste), (D) Portlandite in hexagonal plate shape among hardened mortar paste, (E) Calcite formed in pores.

\section{4. 복원부 모르타르의 중성화 실험}

모르타르는 수화반응 시 생성되는 수산화칼슘으로 인 해 강알카리성을 나타내는데, 수화반응 후 오랫동안 대기 중에 노출되면, 표면에서 공기 중의 이산화탄소 $\left(\mathrm{CO}_{2}\right)$ 의
작용을 받아 서서히 중성화(탄산화)가 진행된다. 이 연구 에서는 앙화, 옥개석 외부, 옥개석 내부, 탑신석에서 수습 한 시료를 바탕으로 중성화 상태를 확인하기 위해 중성화 반응검사를 하였고, $\mathrm{pH}$ 측정을 통해 중성화 진행 정도를 분석하였다. 
Table 4. Classification of sample location and sample type

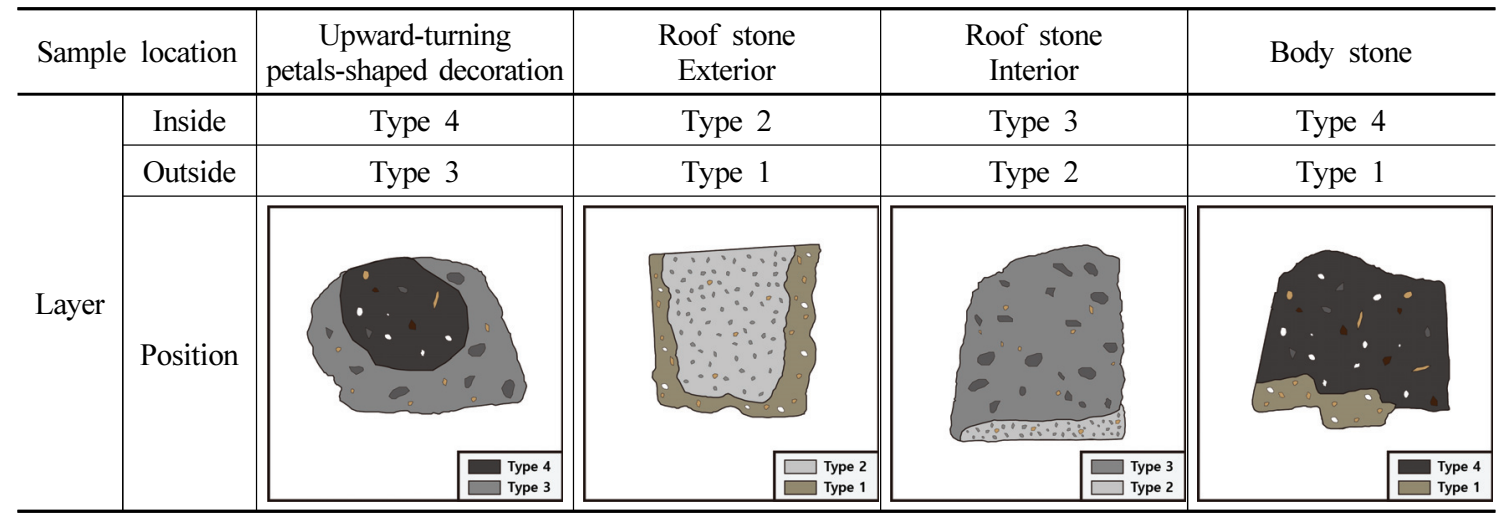

\section{1. 시료 및 실험방법}

시료는 3 개의 부재에서 4점을 선별하였는데, '3. 복원 부 모르타르의 재료학적 특성'에서 기준한 Type 1 4에 서 대표성을 지닌 시료로 $\mathrm{pH}$ 측정과 중성화 반응 검사를 진행하였다(Table 4).

$\mathrm{pH}$ 측정은 모르타르의 수소이온활량을 나타내는 값으 로 숫자가 낮을수록 산성화가 진행됨을 지시한다. 따라서 $\mathrm{pH}$ 값을 통해 재료의 물성 안정도를 파악할 수 있는 지표 가 될 수 있다. 실험은 $\mathrm{KS} \mathrm{F} \mathrm{2103(흙의} \mathrm{pH}$ 값 측정 방법)의 방법을 준용하였고, $\mathrm{pH}$ 측정기(Thermo Scientific, Orion 3-star benchtop pH Meter)를 이용하였다.

중성화 반응 검사는 콘크리트의 노화 진행 정도를 알 아보기 위한 가장 대표적인 방법으로 중성화가 진행 중이 면 원형부재와 접촉면에 풍화를 촉진시킬 수 있는 요인이
잔존하고 있음을 의미한다. 검사 방법은 페놀프탈레인 $1 \%$ 용액을 충분히 분무하여 변색 양상을 관찰하는 것으 로 $\mathrm{pH}$ 0 8.3은 무색, $\mathrm{pH} 8.3 \sim 10$ 은 분홍색, $\mathrm{pH} 10$ 이상은 빨간색을 나타내며, 자적색으로 변하지 않는 부분이 중성 화가 진행된 것을 나타낸다.

\section{2. 실험결과}

열화 정도를 알아보기 위해 먼저 각 시료의 $\mathrm{pH}$ 를 측정 하였다. 측정 결과, 중성화 기준을 $\mathrm{pH} 8.5 \sim 10$ 으로 볼 때 평균 11.57(11.43 11.69)로 알카리성을 띠지만 강우에 직 접 노출되는 옥개석 외부는 상대적으로 낮아 중성화가 진 행 중임을 알 수 있다. 모든 시료가 $\mathrm{pH} 11$ 이상을 보이므 로 중성화가 진행 중이라 판단된다(Figure 7).

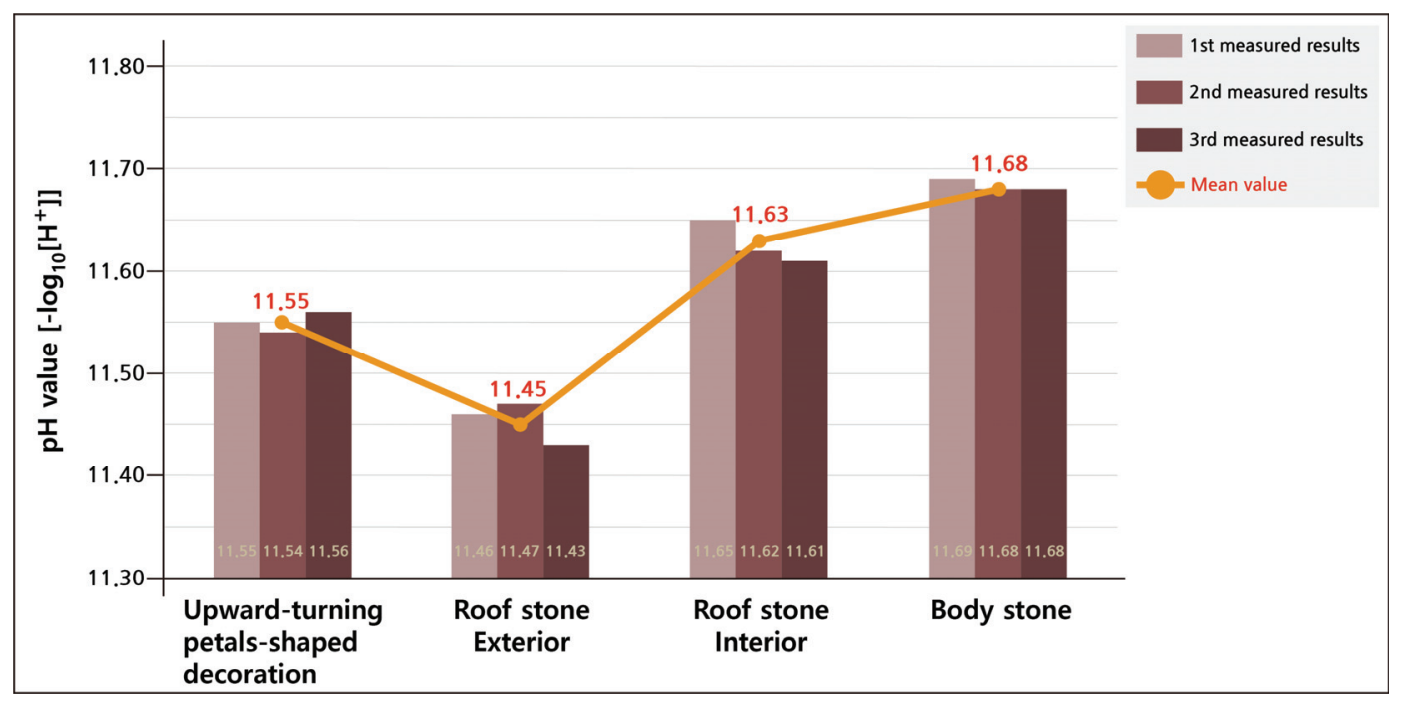

Figure 7. $\mathrm{pH}$ measurement results. 


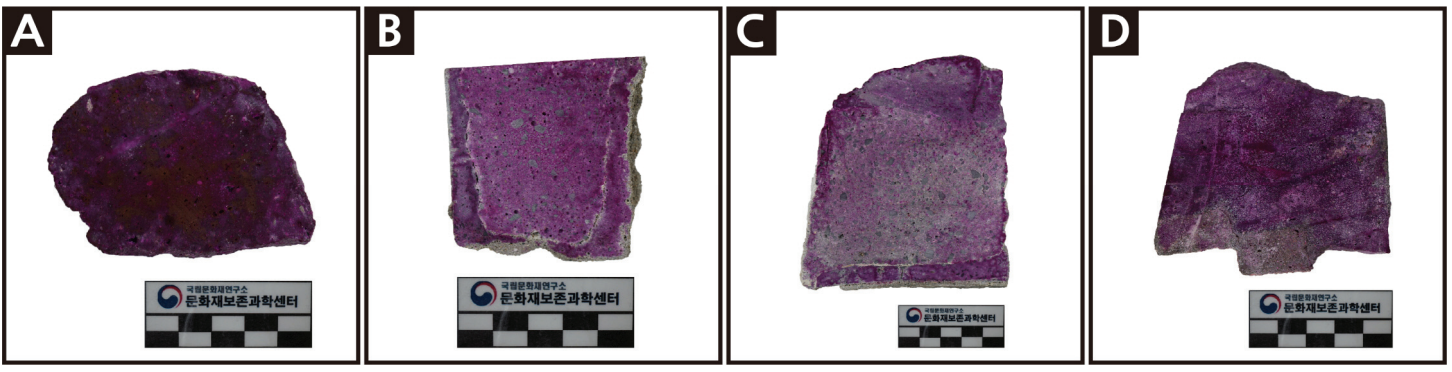

Figure 8. Neutralization test of mortar samples. (A) Upward-turning petals-shaped decoration, (B) Roof stone Exterior, (C) Roof stone Interior, (D) Body stone.

중성화 반응 검사 결과, 옥개석 외부의 바깥 테두리 부 분에서 부분적으로 무색을 보였고(Figure $8 \mathrm{~B}$ ), 옥개석 내 부에서는 일부 색변화가 나타나지 않았다(Figure $8 \mathrm{C}$ ). 탑 신석의 경우 유형 1 이 다른 곳에 비해 색변화가 미비하게 나타남으로써(Figure $8 \mathrm{D}$ ) 각 시료의 위치마다 중성화 속 도가 다르게 나타나고 있음을 알 수 있다.
두 실험에서 $\mathrm{pH}$ 결과는 안정적으로 보여질 수 있지만, 중성화 반응 검사 시 색이 나타나지 않는 부분을 확인함 으로써 종합적으로 열화가 진행 중임을 판단할 수 있다. 이는 선행연구인 반전위측정방법을 적용한 모르타르의 부식손상 가능성이 $90 \%$ 이상이라는 분석결과처럼 원형 부재 표면과 접합계면 등에 손상을 유발할 수 있는 요인 이 잔존하고 있음을 지시한다(Lee et al., 2018).

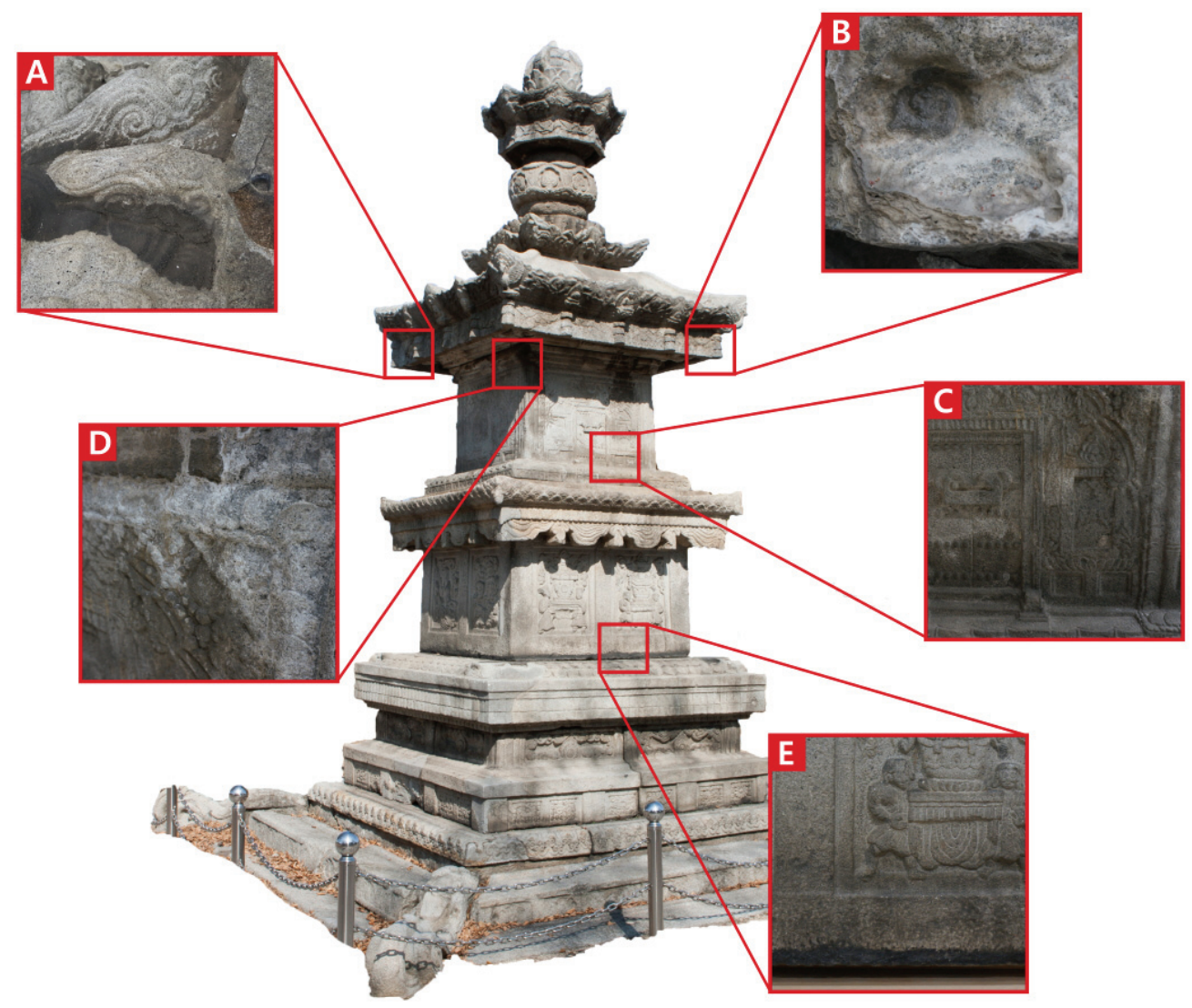

Figure 9. Sample location of surface contaminants. (A) Roof stone_Black crust, (B) Roof stone_White crust, (C) Body stone Black crust, (D) Body stone White crust, (E) Upper stylobate stone Black crust. 


\section{5. 표면오염물 분석}

\section{1. 표면오염물 시료 위치}

지광국사탑에 발생한 오염물에 대한 성분을 규명하고 발생 원인을 해석하기 위해 분석을 진행하였다. 오염물이 농집되어 있는 부분에서 흑색과 백색오염물을 수습하였 고(Figure 9), 수습한 시료는 SEM-EDX와 XRD분석을 통 해 정성·정량 분석하였다.

\section{2. 분석결과}

\subsection{1. 표면오염물의 미세조직 관찰}

옥개석 흑색오염물은 장미꽃 모양의 이수석고 $\left(\mathrm{CaSO}_{4}\right.$ • $2 \mathrm{H}_{2} \mathrm{O}$ )가 형성되어 있고(Figure $10 \mathrm{~A}$ ), 백색오염물은 현미 경 관찰 결과 얇은 판상으로 오염물이 겹겹이 쌓인 모습 을 볼 수 있었는데, 주사전자현미경에서 원형부재의 조암 광물들 위에 방해석 $\left(\mathrm{CaCO}_{3}\right)$ 이 성장하는 모습이 확인된다 (Figure 10B). 탑신석 흑색오염물의 경우 적란운 형태로

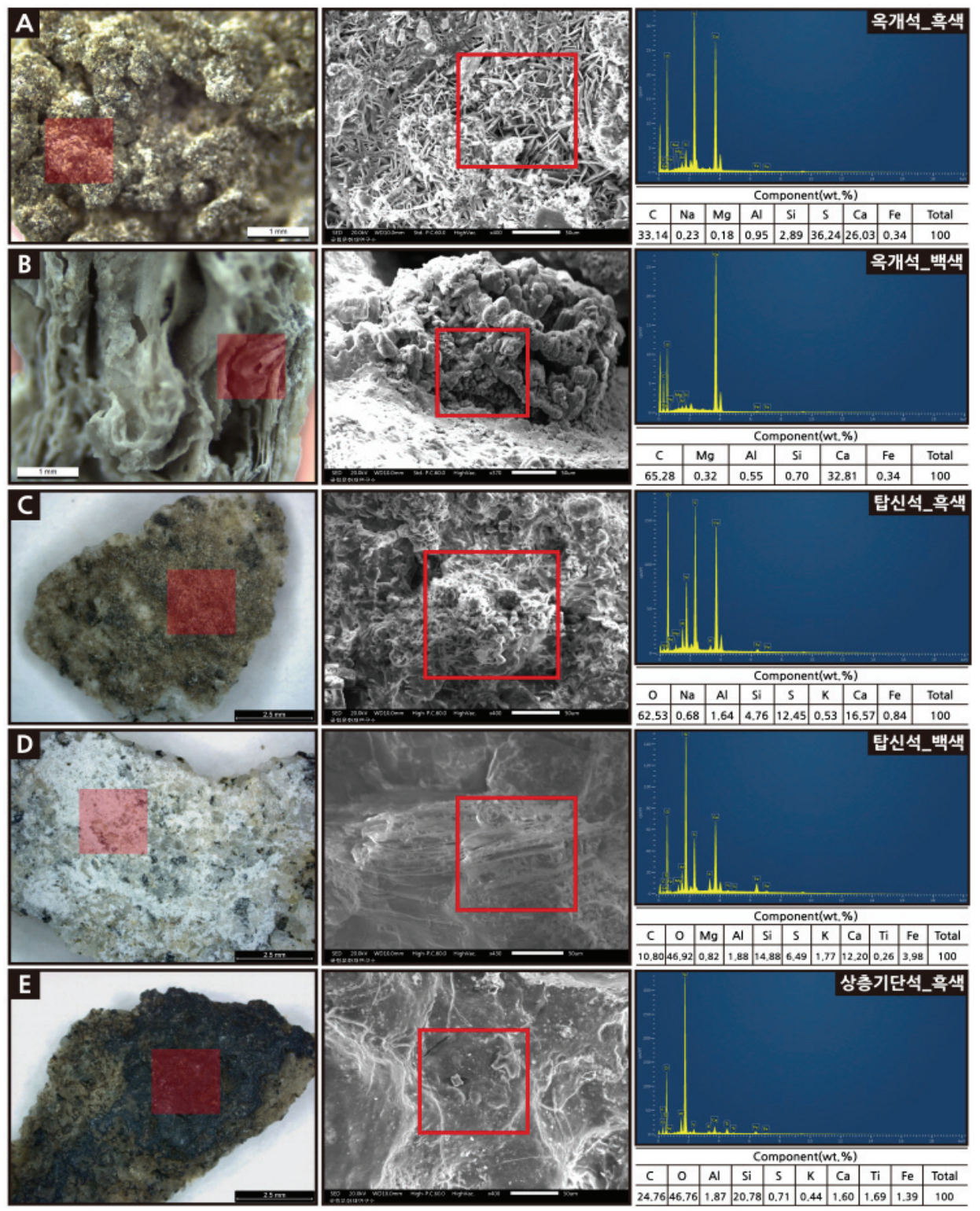

Figure 10. Microscope images \& Scanning electron microphotographs and energy dispersive spectrum of analyzed surface contaminant samples. (A) Roof stone_Black crust, (B) Roof stone_White crust, (C) Body stone_Black crust, (D) Body stone White crust, (E) Upper stylobate stone Black crust. 
형성된 방해석과 그 사이에 성장 중인 이수석고를 확인하 였고(Figure 10C), 백색오염물은 깨진 석영 광물 사이로 방해석이 성장 중이었다(Figure 10D). 상층기단석 흑색오 염물은 앞서 다른 오염물에서 볼 수 있었던 방해석이나 이수석고는 관찰되지 않았기 때문에, 탄소에 기인한 흑색 오염물로 추정된다(Figure 10E).

\subsection{2. 표면오염물의 $X$ 선 회절분석}

오염물은 암석 구성 광물 외에 방해석 $\left(\mathrm{CaCO}_{3}\right)$ 과 이수
석고 $\left(\mathrm{CaSO}_{4} \cdot 2 \mathrm{H}_{2} \mathrm{O}\right)$ 가 동정되었다. 특히 옥개석 흑색오 염물은 이수석고의 회절피크가 강하게 나타났고, 옥개석 의 백색과 탑신석의 흑색 및 백색은 암석기원에서 확인 되지 않는 방해석 결정피크가 강하게 확인되는데 이는 모르타르에서 기인한 것으로 판단된다. 반면 상층기단석 의 흑색오염물은 암석 구성 광물만 동정되었는데, 상대 적으로 모르타르의 영향이 낮은 이유로 판단된다(Figure 11).

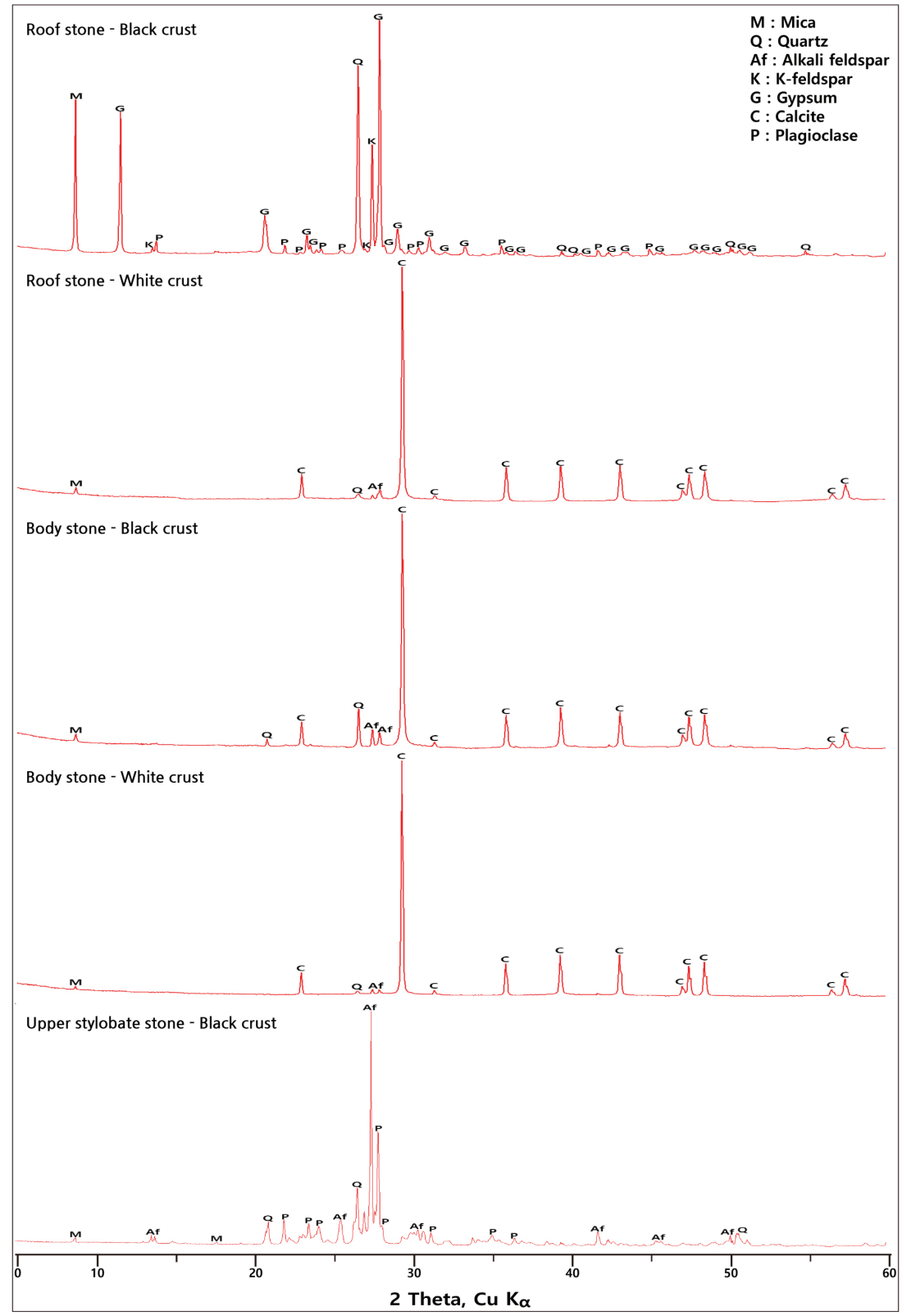

Figure 11. Analysis results of surface contaminant samples by X-ray diffraction patterns. 


\section{3. 오염물에 따른 원형부재 손상 해석}

앞서 분석된 결과를 바탕으로 표면손상 및 염 결정 형 성에 가장 큰 영향을 미치는 $\mathrm{Ca}$ 와 $\mathrm{S}$ 의 함량을 비파괴분석 장비인 P-XRF(Innov-X System, a-6000)를 이용하여 반정 량분석을 실시하였다. 비교 분석대상은 문양 조각이 새겨 져 있고 모르타르에 직접 영향을 받은 탑신석과 상대적으 로 영향이 미미한 상층기단석을 선정하였다. 측정 방식은 분석 지점에 따른 등고밀도선 방식으로 $2 \mathrm{D}$ 모델링하여 원소의 분포와 농도를 나타낸 후, 두 부재의 물리적 손상 을 도시하였다(Figure 12).

분석 결과, 탑신석의 남면에서 $\mathrm{Ca}$ 와 $\mathrm{S}$ 의 농도가 높게 나타났는데, 이와 유사한 영역으로 표면 문양의 박리와 박락이 진행 중이었다. 이와 달리 상층기단석의 경우 모 서리 부분의 미세박락과 하단의 흑색오염물만 확인되었 다. 이는 모르타르로부터 기인한 $\mathrm{Ca}$ 와 $\mathrm{S}$ 성분이 원형부재 의 표면손상 및 염 풍화에 영향을 미치고 있음을 상대적 으로 보여주고 있다.

\section{6. 고찰 및 결론}

수용성 염은 건조한 환경에서 결정화 과정을 거치면서 박리, 박락, 입상분해 등의 다양한 형태로 손상을 입히는 데, Winkler(1994)와 Rijniers(2004)의 연구에서는 염 손상 의 대표적 3요인을 수화(Hydration), 차별적 열팽창 (Differential dilatation), 결정압(Crystalization pressure)으로 밝힌바 있다. 수화현상은 결정이 형성된 후 습한 환경에 서 결정이 팽창하는 현상이고, 차별적 열팽창은 급격한 온도 상승에 따라 결정이 팽창하는 현상이다. 결정압은 조직에서 결정이 성장함에 따라 기공과 벽에 가하는 압력 을 의미하며 기공이 결정 크기와 같거나 작은 경우에는 조직에 손상을 가할 수 있다(Jang et al., 2009). 특히 석재 에 침투한 염은 용해도의 차이와 주변 환경의 영향으로 석재의 표면 또는 내부로 이동하여 결정화 작용을 거치게 되는데, 석재 표면에 침착되는 현상을 백화(efflorescence), 내부에서 결정화되는 현상을 내부결정화(Subflorescence)

\section{Body stone}

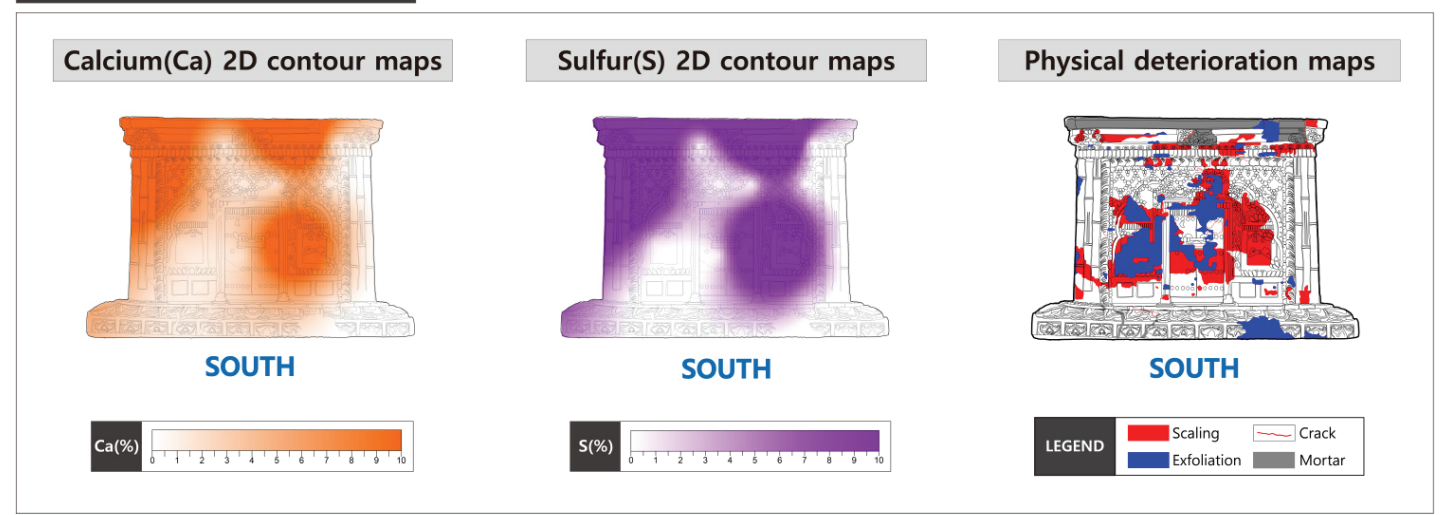

\section{Upper stylobate stone}

Calcium(Ca) 2D contour maps

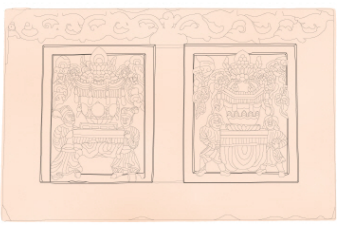

SOUTH
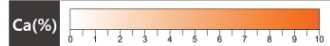

Sulfur(S) 2D contour maps

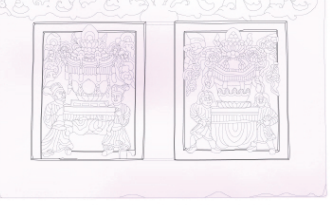

SOUTH

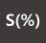

Physical deterioration maps

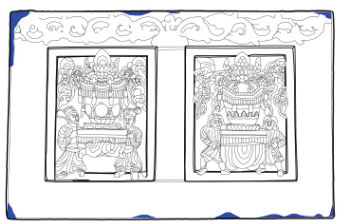

SOUTH

Figure 12. Concentrations of $\mathrm{Ca}$ and $\mathrm{S}$ analyzed by $\mathrm{P}-\mathrm{XRF}$ in $2 \mathrm{D}$ mapping \& Physical deterioration maps of the Body stone and Upper stylobate stone(Physical deterioration maps by Cultural Heritage Conservation Science Center, 2017). 
로 정의되며, 내부결정화(Subflorescence) 작용이 발생할 경우 염은 석재 내부에서 결정화되면서 압력이 발생한다 (Lee et al., 2013). 일반적으로 석조문화재의 손상양상에 서 백화 및 흑화현상의 주된 요인은 방해석이나 석고와 같은 염, 분진으로 알려져 있다. 염과 분진에 의한 흑화현 상은 대기오염이 심각한 지역에서 주로 나타나는데, 대기 중의 황산가스, 탄산가스 및 질산가스는 암석 내외부에서 기원한 칼슘, 칼륨 및 나트륨 등과 반응하여 염 결정을 형성한다. 이러한 과정에서 정출되는 오염물은 석조문화 재 표면에 피각상으로 나타나면서 공극의 확장과 박리, 박락을 발생시킨다(National Research Institute of Cultural Heritage, 2011). 앞서 Chun and Lee(2016) 선행연구에서도 원각사지십층석탑의 표면손상 원인을 대기오염물질인 황(S)의 영향으로 형성된 이수석고 $\left(\mathrm{CaSO}_{4}, \mathrm{Gypsum}\right)$ 에 의 한 것으로 정리하였다. 시멘트로 복원된 지광국사탑 역시 복원 후 60 여 년이 넘게 원각사지십층석탑과 비슷한 환경 인 서울 도심지의 대기에 노출되어 있었다. 이로 인해 산 성비 기원의 산 침식에 의한 열화 현상과 대기 중 이산화 탄소로 인한 중성화 작용은 피해 갈 수 없었을 것이다. 해체 전 손상양상을 살펴보면 옥개석 하부에서 탑신석으 로 백색 오염물질이 흘러내린 것을 확인할 수 있으며, 이 는 모르타르의 열화로 인해 용해된 석회물질들이 흘러내 려 원형부재에 지속적인 손상을 가하고 있었음을 의미한 다. 앞서 복원부 모르타르 분석결과, 수산화칼슘 $\left(\mathrm{Ca}(\mathrm{OH})_{2}\right)$, 방해석 $\left(\mathrm{CaCO}_{3}\right)$, 에트링자이트 $\left(3 \mathrm{CaO} \cdot \mathrm{Al}_{2} \mathrm{O}_{3} \cdot 3 \mathrm{CaSO}_{4} \cdot 32 \mathrm{H}_{2} \mathrm{O}\right)$, 이수석고 $\left(\mathrm{CaSO}_{4} \cdot 2 \mathrm{H}_{2} \mathrm{O}\right)$ 가 동정되었고, $\mathrm{pH}$ 측정과 중성화 반응 검사를 통해 모르타르 열화가 진행 중임을 확인할 수 있다. 따라서 복원부 모르타르의 반응생성물들은 원형 부재에 영향을 미치는 중요 인자로 작용한 것으로 보인 다. 이는 선행연구인 반전위측정방법을 적용한 모르타르 의 부식손상 가능성이 $90 \%$ 이상이라는 분석 결과처럼 복 원부 모르타르는 이미 상당부분 손상이 진행 중인 것으로 판단된다(Lee et al., 2018).

수산화칼슘에서 기원하는 표면오염물 대부분을 차지 하는 방해석 $\left(\mathrm{CaCO}_{3}\right)$ 과 이수석고 $\left(\mathrm{CaSO}_{4} \cdot 2 \mathrm{H}_{2} \mathrm{O}\right)$ 는 난용성 물질로 상 변이를 진행하여 표면에 고착됨으로써 제거를 어렵게 하고, 조암광물 사이에서 염 성장을 촉진시킴으로 써 표면손상 속도를 증가시킨다(Do, 2003). 특히 석조물 에서 나타나는 이수석고와 같은 염은 조해성과 강한 흡습 성이 있기 때문에, 석조물 표면에 부착되었을 시 주변의 수분을 흡수하고 공기 중의 모래나 먼지, 부유물질 등 색 을 띤 분진의 침강을 도와 석조문화재 표면에 오염물을 생성시키는데, 이는 석조물 표면이 유색 또는 흑색을 띠 는 데 영향을 미치게 된다.
표면오염물 분석결과, 옥개석과 탑신석의 오염물에서 방해석 $\left(\mathrm{CaCO}_{3}\right)$ 과 이수석고 $\left(\mathrm{CaSO}_{4} \cdot 2 \mathrm{H}_{2} \mathrm{O}\right)$ 를 확인하였다. 반면 상층기단석의 흑색오염물은 원형부재 광물조성만 이 동정되어, 해당 결과의 교차 검증을 위해 모르타르의 직접적 영향을 받은 탑신석과 간접적 영향을 받은 상층기 단석을 휴대용 XRF를 이용하여 반정량 분석하였고, 그 결과 원소의 분포와 농도를 표면손상 양상과 비교하였다. 앞서 지광국사탑 원형부재의 구성암석에 관한 연구 결과, 탑신석과 상층기단석은 세립질 흑운모화강암으로 석영, 미사장석, 사장석, 정장석, 흑운모로 구성된 것으로 밝혀 진바 있다(Cultural Heritage Conservation Science Center, 2018). 시간에 따른 풍화로 장석에서 기인한 $\mathrm{Ca}$ 의 영향을 배제할 수는 없지만, 같은 암석으로 만들어진 탑신석과 상층기단석을 비교해보면 특징적으로 탑신석에서만 보 이는 $\mathrm{Ca}$ 와 $\mathrm{S}$ 의 높은 농도는 모르타르의 직접적 영향에 기인한 것으로 예측할 수 있다. 더불어 섬세한 문양 조각 으로 인한 화강암 표면에 스트레스가 작용했을 부분을 배 제할 순 없지만, 미세조직 관찰 시 조암광물 사이로 성장 중인 방해석을 확인하였다(Figure 10D). 이러한 연구 결과 는 복원된 모르타르에서 기원한 오염물의 성분이 지광국 사탑 표면에 손상을 가하고 있는 것으로 보이며, 이 기초 해석을 참고하여 각 모르타르의 층위별 풍화산물 분석과 그에 따른 암석의 역학관계를 좀 더 규명하기 위한 손상 메커니즘 추가 연구를 진행할 예정이다.

\section{사 사}

이 연구는 국립문화재연구소 문화유산조사연구(R\&D) 사업의 일환으로 수행되었으며 이에 감사한다.

\section{REFERENCES}

Chun, Y.G., Lee, M.S., Kim, Y., Lee, S.M. and Lim, B.A., 2016, Forming process of surface contaminants on tenstory stone pagoda of Wongaksa temple, Seoul. Journal of Conservation Science, 32, 365-375. (in Korean with English abstract)

Cultural Heritage Conservation Science Center, 2017, Report of conservation and restoration of State Preceptor Jigwang Stupa from Beopcheonsa temple Site in Wonju. 1, 54-141. (in Korean)

Cultural Heritage Conservation Science Center, 2018, Report of conservation and restoration of State Preceptor Jigwang Stupa from Beopcheonsa temple Site in Wonju. 2, 83-92. (in Korean)

Do, J.Y., 2003, Characteristics and origin of salts in the 
black surface layer of stone monuments. Journal of Conservation Science, 12(1), 15-25. (in Korean with English abstract)

Jang, S.Y., Nam, B.J., Park, D.W., Kang, H.M., and Jung, Y.H., 2009, A study on the soluble salt and deterioration of ceramics from Taean Shipwreck. Conservation Studies, 30, 189-202. (in English abstract)

Kim, D.G., Kim, S.S., Lee, S.T., and Kim, J.P., 2006, The method of durability increase on the concrete structure considering chemical attack. Magazine of the Korea Concrete Institute, 18(4), 49-56.

Lee, M.H., Chun, Y.G., Lee, M.S., 2013, Deterioration mechanism interpretation and surface contaminant analysis of the five-storied stone pagoda in Tapriri, Uiseong. Economic and Environmental Geology, 46(5),
445-453. (in Korean with English abstract)

Lee, T.J., Cho, H.J., Park, H.J. and Chae, S.A., 2018, The condition evaluation of mortar parts of Stupa of State Preceptor Jigwang from Wonju Beopcheonsa temple site by half cell potential measurement, Journal of Conservation Science, 34(6), 503-515. (in Korean with English abstract)

National Research Institute of Cultural Heritage, 2011, Cleaning and Surface Contaminant of Stone Cultural Heritage, 8-11. (in Korean)

Rijniers Lourens Albert, 2004, 'Salt crystallization in porous materials: and NMR study', Ph.D. research at Eindheven University of Technology.

Winkler, E.M., 1994, Stone in architecture, 3ed., Springer-Verlag, Germany, 166. 